\title{
Zircon U-Pb strain chronometry reveals deep impact-triggered flow
}

\author{
D.E. Moser ${ }^{1 *}$, W.J. Davis ${ }^{2}$, S.M. Reddy ${ }^{3}$, R.L. Flemming ${ }^{1}$, R.J. Hart ${ }^{4}$
}

\begin{abstract}
Large $(>100 \mathrm{~km})$ meteorite impact cratering events play important roles in surface and biosphere evolution, however, their potential for widespread ductile modification of the lithosphere has been difficult to assess, due partly to our inability to isotopically agecorrelate deep mineral fabrics with surface records. We have integrated benchmark U-Pb zircon dating methods (ID-TIMS, SHRIMP) with new microstructural techniques (EBSD, $\mu \mathrm{XRD})$ to demonstrate that crystal-plastic deformation can cause rapid out-diffusion of radiogenic $\mathrm{Pb}$ and accompanying trace element alteration in crystalline zircon. We have used this phenomenon to directly date fabric in Archean zircons and xenoliths of the lower crust of South Africa at $2023 \pm 15$ million years, coeval with the $2020 \pm 3$ million year old Vredefort cratering event at surface, with extent $\geq 20,000 \mathrm{~km}^{2}$. Our findings indicate that regional exogenic fabrics, similar to high-temperature tectonic fabrics, exist in ancient crust. Moreover, our results establish that crystal-plastic deformation in the lithosphere can now be directly dated and linked to planetary evolution by zircon U-Pb strain chronometry.
\end{abstract}

$1^{*}$ corresponding author Dept. of Earth Sciences, University of Western Ontario, London, ON, Canada N6A 5B7; desmond.moser@uwo.ca, tel: 519-661-4214

${ }^{2}$ Geological Survey of Canada, 601 Booth St., Ottawa, Canada, K1A 0E8

${ }^{3}$ Dept. of Applied Geology, Curtin University of Technology, GPO Box U1987, Perth, WA 6845, Australia

${ }^{4}$ iThemba labs, P. Bag 11 Wits 2050, Johannesburg, South Africa 


\section{Introduction}

46 The rebound and isostatic recovery of multi-kilometer deep impact craters, more

47 prevalent on the early Earth, can potentially generate permanent strain in the deep

48 lithosphere (Ivanov, 2005; Nimmo et al., 2008). The nature of any resulting strain fabrics,

49 however, remains poorly understood due partly to a rarity of samples to test the concept,

50 but also because accurate, direct age correlation of fabrics to impact or short-lived,

51 tectonic events has proved intractable to isotopic dating techniques, including the

52 benchmark zircon $\mathrm{U}-\mathrm{Pb}$ method. The integrity of zircon as a geochemical capsule

53 preserving primary isotopic and trace element information, unaffected by deformation, is

54 fundamental to the accurate measurement of events in geologic and planetary evolution

55 (e.g. Holmes, 1911; Wilde et al., 2001; Srinivasan et al., 2007). In the continental crust,

56 experimental data demonstrate that thermally-controlled volume diffusion alone should

57 not affect the chemistry of non-metamict zircon particularly in the plastically deforming

58 middle and lower crust where ambient temperatures above $\sim 150^{\circ} \mathrm{C}$ prompt rapid repair of

59 alpha- decay lattice damage (Meldrum et al., 1998). Crustal strain-induced Pb diffusion

60 and associated isotopic age re-setting and "discordance" (Wetherill, 1956) in zircon has

61 been proposed (Wayne and Sinha, 1988) but has not yet been demonstrated due to

62 partially metamict samples or possibly because research (e.g. Ashwal et al., 1999)

63 predated advances in microstructural analysis of crystal-plastic zircon deformation

64 (Reddy et al., 2006; Reddy et al., 2007). Here we apply advanced microstructural analysis

65 along with high spatial and isotopic resolution $\mathrm{U}-\mathrm{Pb}$ zircon dating to mylonitized lower

66 crustal xenoliths from beneath the Witwatersrand basin of South Africa to determine the

67 age and origin of their mineral fabrics. 


\subsection{Geological Context}

69 The lower crustal xenoliths were recovered from the Lace kimberlite pipe that

70 intruded at $0.132 \mathrm{Ga}$ (Phillips et al., 1998), $60 \mathrm{~km}$ from the present geographic center of

71 the deeply eroded Vredfort impact basin in the eastern Kaapvaal craton (Fig. 1). The

72 craton is a remnant of thick, diamondiferous Mesoarchean (3.5 to 3.1 Ga) lithosphere that

73 was coherent by $3.08 \mathrm{Ga}$ (Moser et al., 2001) after which its western margin experienced

$742.9 \mathrm{Ga}$ orogenesis followed by $2.7 \mathrm{Ga}$ Ventersdorp continental rifting and coeval ultra

75 high-temperature metamorphism of the lower crust (Schmitz and Bowring, 2003).

76 Structural modification, impact melting and local metamorphism of the basement to the

77 gold-rich upper crust occurred at $2.020 \pm .003 \mathrm{Ga}$ as a result of the Vredefort impact

78 (Spray et al., 1995; Moser, 1997) that formed a crater with a final diameter of $\sim 250 \mathrm{~km}$

79 and maximum depth of excavation of $\sim 10 \mathrm{~km}$ (Henkel and Reimold, 1998). Shock

80 pressures experienced by the base of the $>38 \mathrm{~km}$ Kaapvaal crust (Nguuri et al., 2001)

81 beneath the Lace pipe would have been less than the $20 \mathrm{GPa}$ threshold for shock

82 deformation of zircon (Leroux et al., 1999) due to shock wave attenuation of $\sim 4 \mathrm{GPa} / \mathrm{km}$

83 over the radial distance of $\sim 80 \mathrm{~km}$ from the original point of impact (Gibson and

84 Reimold, 2005). Microstructural features indicative of shock metamorphism have not

85 been reported in zircon or main phase assemblages in previous petrologic investigations

86 of the Lace lower crustal xenolith suites (Dawson et al., 1997; Schmitz and Bowring,

87 2003). Shock wave heating is also predicted to have been insignificant at this region of

88 the crust (Henkel and Reimold, 2002) where, after decay of the Ventersdorp thermal

89 pulse, ambient temperatures cooled from $650^{\circ} \mathrm{C}$ to $350^{\circ} \mathrm{C}$ (Gibson and Jones, 2002), i.e.,

90 consistently above the self-annealing temperature of zircon radiation damage. 


\section{Methods}

92 High precision, $\mathrm{U}-\mathrm{Pb}$ isotope geochronology was performed first by applying isotope

93 dilution thermal ionization mass spectrometry (ID-TIMS) on air-abraded single zircons or

94 CL-imaged zircon fragments at the Jack Satterly Geochronology Laboratory, Royal

95 Ontario Museum/University of Toronto using methods described in Moser and Heaman

96 (1997). Details of analytical corrections and U-Pb isotopic spike are provided in Table 1.

97 Zircon internal structure and lattice orientation in thin sections and polished grain mounts

98 were measured at the University of Western Ontario using colour SEM-

99 Cathodoluminescence (SEM-CL) and a microbeam (50 $\mu$ m diameter) X-ray

100 diffractometer $(\mu \mathrm{XRD})($ Flemming, 2007). SIMS spot analyses of $\mathrm{U}-\mathrm{Th}-\mathrm{Pb}$ isotopes and

101 trace elements at the Geological Survey of Canada SHRIMPII laboratory were performed

102 prior to Electron Backscatter Diffraction (EBSD) mapping of the SHRIMPII grain mount

103 at the Curtin University of Technology. Details on analytical protocols and run conditions

104 employed in these techniques are provided as Supplementary Material.

\section{3. Results of zircon analysis}

The Lace mafic xenoliths feature a primary assemblage of garnet-clinopyroxene-

108 plagioclase-quartz that is typical of high pressure (0.9 $\mathrm{GPa}$ to $1.2 \mathrm{GPa})$ granulite facies

109 samples of the lower continental crust (Pattison, 2003). These exhibit mylonitic planar

110 fabrics (Fig. S1) commonly produced by high temperature ductile strain (Snoke and

111 Tullis, 1998). Detailed analysis was carried out on five mafic mylonite xenoliths (LG-

$1121,2,3,5$ and 6 ), between 3 and $5 \mathrm{~cm}$ in maximum dimension, that feature garnet

113 porphyroclasts in a fine-grained groundmass of anhedral clinopyroxene, plagioclase, 
114 garnet, quartz and oxide minerals with trace zircon and apatite (Fig. S1). Xenolith LG2

115 contained a leucocratic layer (LG2b) that was processed for zircon separation separately

116 from the main mass (LG2a). Zircons occur as inclusions in the garnet porphyroclasts as

117 well as at grain boundaries of mylonitized matrix minerals (Fig. 2) and are optically

118 continuous, light to dark pink, high-luster grains with forms ranging from subhedral long-

119 prismatic to round, highly-embayed anhedra.

120 3.1. Cathodoluminescence and $\mu X R D$

121 The zircon internal structure revealed by SEM-CL consists of three zones; Type 1

122 igneous, planar growth-banded cores, Type 2 brightly luminescent, rounded metamorphic

123 rims and Type 3 complexly zoned domains of intermediate CL intensity and indistinct

124 'cloudy' to discontinuous banding occurring at cores and/or rims of grains (Fig. 2). In

125 situ $\mu \mathrm{XRD}$ analysis of an elongate Type 1 and 2 zoned zircon within the core of a garnet

126 porphyroclast (LG-6) gives a discrete point reflection pattern for zircon (112) and (431)

127 planes and enclosing garnet plane (312) consistent with undeformed single crystals. Two

128 ovoid zircons near the mylonitized margin of the garnet porphyroclast show distorted

129 core/rim boundaries and nebulous type 3 CL zoning, and yield arcs or streaks of X-ray

130 reflectors indicating strain within the crystal (Flemming, 2007) and a mosaicity of 3

131 degrees. Neighboring feldspar and clinopyroxene show even greater mosaicity and lattice

132 deformation consistent with undulose extinction patterns apparent in polarized light

133 microscopy. A Type 3 zircon within the mylonitic foliation of xenolith LG-5 yielded a

134 similar $\mu \mathrm{XRD}$ pattern consistent with crystal-plastic deformation.

135 3.2. U-Pb isotope and trace element composition 
Prior to microstructural analysis, single zircons or zircon fragments exhibiting a

137 range of morphology and zoning types were analyzed by ID-TIMS. The results range

138 from concordant to $60 \%$ discordant along a discordia line with intercepts at $2670 \pm 4 \mathrm{Ma}$

139 and $2015 \pm 18 \mathrm{Ma}(\mathrm{MSWD}=0.42)$ (Fig. 3; table 1; all $\mathrm{U}-\mathrm{Pb}$ data reported at $2 \sigma$ confidence).

140 The collinearity of the data from the five different xenoliths suggests a common history

141 for the xenolith source region beginning at $2.67 \mathrm{Ga}$, whereas the high precision of the

142 single grain analyses clearly indicates discordance relating to an episode at $2.02 \mathrm{Ga}$. To

143 identify the discordant domains within single grains, 64 SHRIMP II analyses were carried

144 out on grains from LG1 (8 grains), LG-2a (14 grains) and LG-2b (7 grains) (Fig. 3; table

$145 \mathrm{~S} 1$ ). Type 1 cores and type 2 rims yield ages of $2.67 \mathrm{Ga}$, plotting at or near the upper

146 concordia intercept determined by ID-TIMS (Fig. 3). The weighted mean ${ }^{207} \mathrm{~Pb} /{ }^{206} \mathrm{~Pb}$ age

147 of $2663 \pm 7 \mathrm{Ma}(\mathrm{MSWD}=0.39)$, determined from the eight most concordant Type 1 cores,

148 is within error of the weighted mean ${ }^{207} \mathrm{~Pb} /{ }^{206} \mathrm{~Pb}$ age of $2654 \pm 12 \mathrm{Ma}$ determined for Type

1492 rim domains. Trace element measurements of cores and rims by SHRIMPII reveal large

150 changes in $\mathrm{U}$ and HREE concentration (table S2). Type 1 cores exhibit high [U] (870 to

$1511800 \mathrm{ppm}, \mathrm{n}=4$ ) and elevated HREE abundances typical of igneous zircon (Hoskin and

152 Black, 2000), whereas rims are markedly lower in relative [U], Th/U and HREE.

153 The Type 3 zones were found to be the source of discordant data with individual

154 analyses plotting from $30 \%$ to $100 \%$ down the discordia line (Fig. 3). The greatest

155 discordance was measured in Grain 17 of xenolith LG-2A where multi-spot analyses ( $\mathrm{n}=$

156 15) allow contouring of the pattern of discordance in the grain interior (Fig. 4).

157 Discordance is at a minimum at grain edges and increases to maximum values of $100 \%$ in

158 a central corridor (Fig. 4). The weighted mean of the 6 youngest ${ }^{207} \mathrm{~Pb} /{ }^{206} \mathrm{~Pb}$ ages from the 
central zone is $2023 \pm 15$, within error of the ID-TIMS lower intercept age of $2018 \pm 15$

160 Ma. Trace element analysis reveals variations in [U] across the grain unrelated to the

161 degree of discordance (fig. S2, table S2). Discordance instead correlates with LREE

162 abundance, with a five-fold relative increase in Ce abundance, and a $\mathrm{La} / \mathrm{Sm}$ ratios

163 increase from 0.02 to as much as 0.60 , in the zone of $100 \%$ discordance (fig. S2).

\section{3.3. Zircon crystal-plastic strain and microstructure}

165 Whole-grain strain analysis of Grain 17 by $\mu$ XRD indicates 2 to 3 degrees of 166 mosaicity of the (112), (321) and (301) planes (Fig. 4) - identical to that measured in

167 Type 3 grains in the mylonitic fabric in thin sections of LG-6 and LG-5. Strain mapping 168 of the Grain 17 surface by EBSD, after re-polishing to remove $\sim 1$ micron ion probe pits 169 and following new procedures (Reddy et al. 2007; 2008), reveals pervasive incremental

170 lattice rotation about a central 'shear' defined by a concentration of low angle grain

171 boundaries that coincide with the zone of 100\% discordance (Fig. 4). Automatic EBSD

172 mapping illustrates up to $20^{\circ}$ of cumulative misorientation across the polished grain

173 surface accommodated by low-angle boundaries (Fig. 4). Dispersion of crystallographic

174 axes around numerous small circles (Fig. 4) suggests that multiple slip systems were

175 operating during intragrain deformation.

176 4. Zircon U-Pb strain chronometry

177 Proof of strain-induced $\mathrm{U}-\mathrm{Pb}$ age discordance in zircon must satisfy several

178 conditions: 1) the zircons must have remained above the radiation damage self-annealing

179 temperature of $\sim 150^{\circ} \mathrm{C}$ (Meldrum et al., 1998) before and after deformation in order to

180 preclude the possibility that $\mathrm{U}-\mathrm{Pb}$ age discordance occurred by $\mathrm{Pb}$-loss from radiation-

181 damaged domains; 2) the ductilely deformed (as opposed to recrystallized) zircon 
182 domains must be identified in situ and shown to be contemporaneous with the

183 deformation fabric in the host rock, and 3) the U-Pb isotopic data must be of sufficient

184 analytical and spatial resolution to demonstrate a correlation of discordance with zircon

185 microstructure. We maintain that our investigation fulfills these requirements and

186 demonstrates a clear case of strain-induced Pb-loss in zircon.

187 Evidence that the zircons we have analysed were in the deep crust, and therefore

188 non-metamict, during deformation is derived from the zircon data and regional

189 geophysical/geological constraints. Type 1 oscillatory zoned cores have high U

190 concentrations yet are optically clear and non-metamict in appearance. They yield

191 concordant Archean U-Pb ages by ID-TIMS at $2.670 \pm .004$ Ga and SHRIMP at

$1922.663 \pm .007 \mathrm{Ga}$. Based on the oscillatory zoning structure of the cores, and the extremely

193 sluggish diffusion of $\mathrm{Pb}$ in undeformed, lower crustal zircon during metamorphism (e.g.

194 Moser et al., 2008), these values are interpreted to date the crystallization of the igneous

195 mafic protoliths in the deep crust. The protoliths are seen as deep-seated counterparts to

196 voluminous surface eruption of 2.664 \pm .002 Ga Pneil-stage flood basalts (Barton et al.,

197 1995) late in the Ventersdorp rifting on the western margin of the craton. Evidence for

198 cooling and autometamorphism of the intrusions to form the present garnet granulite

199 facies assemblage is indicated by the dramatic decrease in the abundance of HREE (e.g.

200 Rubatto, 2002) in coeval 2.66 Ga Type 2 zircon rims. This petrogenetic evidence for an

201 intrusive mafic intraplate at the base of the crust is in concert with the sharp increase in

202 seismic wave velocities observed at the Moho of the eastern Kaapvaal craton (Nguuri et

203 al., 2001). Together with the zircon crystallization history, these data are consistent with 
204 residence and deformation of these samples in the lower crust at temperatures in excess

205 of the annealing temperature of zircon radiation damage.

206 The timing relationship between zircon deformation and mylonitization of the

207 host is shown by the in situ $\mu \mathrm{XRD}$ and colour SEM-CL measurements of thin section

208 LG-6. Zircon and host garnet at the center of a porphyroclast are undeformed, the zircon

209 having been armoured by garnet, whereas zircons in the mylonitized edges of the same

210 garnet show clear evidence of crystal-plastic strain (Fig. 2). This spatial association of

211 strained zircon with the petrofabric is critical as it allows us to correlate the timing of

212 zircon deformation to the deformation of the host mineral assemblage. The $\mu$ XRD data

213 for deformed zircons in situ (Fig. 3) and for separated Grain 17 (Fig. 4) are identical, and

214 permit mapping of in situ zircon/petrofabric strain and relative time relationships to the

215 microstructural and absolute age data for Grain 17.

216 A comparison of the lattice strain and isotopic data for Grain 17 reveals the

217 critical link between age discordance and microstructure. The $\mu$ XRD pattern for the

218 entire grain shows short arcs from lattice plane reflectors indicating low angle grain

219 boundaries as opposed to discrete point reflections from a polycrystalline aggregate

220 produced by recrystallization. The EBSD data confirm this and show that low angle

221 boundaries, developed by dislocation creep, define a microstructure that correlates

222 spatially with the central zone of isotopic resetting (Fig. 4). The low variation of [U]

223 across this zone, and the lack of correlation between [U] and discordance in Grain 17 (fig.

$224 \mathrm{~S} 3$, table S1), indicate that discordance is due to Pb-loss rather than U-gain. Based on this

225 spatial correlation of $\mathrm{Pb}$-loss and structure, the low angle grain boundaries are interpreted

226 to mark the location of high diffusivity pathways that facilitated relatively rapid out- 
227 diffusion of $\mathrm{Pb}$ during a ductile flow and mylonite fabric forming event. The detailed

228 mechanisms of fast diffusion are the subject of current investigation, however the relative

229 enrichment of La, Ce and LREE proportional to discordance in Grain 17 (fig. S2, table

230 S2) suggests that diffusion involved participation of a fluid that produced trace element

231 enrichment similar to that reported in domains of crystal-plastic zircon in the lower

232 oceanic crust (Reddy et al., 2006).

\section{5. Implications for planetary processes and chronology}

234 Having established that discordance is caused by lattice strain, and that zircon

235 strain is contemporaneous with mylonitization of the host mineral assemblage, the U-Pb

236 discordia line can be used to construct a first zircon strain chronometry of the lithosphere.

237 In this case the $2.02 \pm 0.02$ Ga lower intercept of the ID-TIMS discordia line, and the

$2382.02 \pm 0.02 \mathrm{Ga}$ average ${ }^{207} \mathrm{~Pb} /{ }^{206} \mathrm{~Pb}$ age of SHRIMP spots $(\mathrm{n}=7)$ for the shear zone at the

239 center of Grain 17, can be interpreted as dating mylonitization of the xenolith samples.

240 As this deformation age is at a time of quiescence in the Kaapvaal craton, and agrees with

241 the $2.020+/-.003 \mathrm{Ga}$ formation of the Vredefort impact basin, mylonite formation is

242 interpreted to be related to impact basin dynamics. Geophysical profiling of the Vredefort

243 impact basin indicates a gentle upward rotation of seismic reflectors at the crust-mantle

244 transition at a geographic distance of $60 \mathrm{~km}$ from center of impact (Durrheim et al.,

245 1991), approximately the same radial distance as the piercing point of the Lace kimberlite

246 pipe (Fig. 5). It has been suggested that tilting of these reflectors could be the result of

247 plastic deformation during crater rebound and return flow (Henkel and Reimold, 1998).

248 Our findings are in concert with this interpretation noting that the $\mathrm{kms}^{-1}$ crustal

249 motions induced by the initial depression and rebound of the transient crater would have 
250 been too great to have been accommodated by mylonite formation in the lower crust. We

251 propose that the fabric we have dated formed in shear zones at the base of the crust

252 during the relatively longer-term recovery of the lithosphere that accompanied post-

253 impact modification and isostatic re-equilibration of the multi-kilometer deep crater.

254 Impact processes are generally radially symmetric and lower crustal mylonitization

255 should have a geographic distribution beneath the crater at least to the distance of the

256 Lace kimberlite. If so, the fabric would extend over $\geq 20,000 \mathrm{~km}^{2}$ of the South African

257 crust-mantle transition. The LREE enrichment of ductile deformed zircon in our sample

258 suggests fluid participation in mylonitization, and such regional flow of the deep crust

259 and related fluid channeling following impact may have played a role in driving the

260 minor remobilization of gold in the overlying deposits of the Witwatersrand basin

261 (Hayward et al., 2005).

262 Our investigation of continental lower crust, and earlier work on oceanic lower

263 crust (Reddy et al., 2006), indicates that ductile deformation of zircon occurs in mafic

264 and/or garnet-bearing lithosphere, and the discovery that this strain can induce minor to

265 complete U-Pb zircon age discordance merits awareness and exploitation. Strain-induced

266 discordance in zircon may explain some low levels of discordance, discordant arrays, or

267 'smears' of U-Pb data along concordia commonly observed in metamorphic rocks (e.g.

268 Ashwal et al., 1999; Harley et al., 2007). On the other hand it should be noted that

269 pronounced strain-induced discordance is exhibited by the minority of zircons in our

270 samples, and these exhibit distinctive CL zoning. Targeting such grains opens the door to

271 the direct dating of lithospheric flow with a corresponding accuracy that has so far eluded

272 geochronology. Regarding the robustness of the zircon strain record, our results are 
273 encouraging as they indicate that low-angle boundaries and associated age disturbance in

274 zircon have persisted at ambient lower crustal temperatures for almost 2 billion years.

275 The abundance of such zones of ductile deformation-altered zircon within the thousands

276 of metamorphic and detrital zircon populations analyzed for geochronology over the last

277 several decades remains to be seen.

278 Our results emphasize that understanding the microstructural state of minerals is

279 important for the correct interpretation of isotopic and trace element data of mineral

280 geochronometers in deformed assemblages and extraterrestrial phases (e.g., Srinivasan et

281 al., 2007; Pidgeon et al., 2007). A more immediate implication is that impact processes

282 can now be considered when interpreting ductile fabric genesis, particularly in ancient,

283 high grade metamorphic terrains where such fabrics are common and surface evidence of

284 large impacts has been lost to erosion. It is hoped that further investigations of the type

285 we have carried out will foster direct measurement of the strain history of the lithosphere

286 of Earth and perhaps other rocky planets, and improve the accuracy of planetary

287 chronologies upon consideration of this new mechanism for generating discordance in

288 zircon.

289 Acknowledgments

290 Support from Prof. T.E. Krogh and Prof. D.J. Schulze (University of Toronto) in

291 launching this research is gratefully acknowledged, as is a National Science and

292 Engineering Research Council Discovery Grant to DEM. Dr. Dazhi Jiang (University of

293 Western Ontario) is thanked for helpful discussions regarding mylonites. Expert drafting

294 was contributed by Patricia Connor (UWO Dept. of Geography). Australian Research

295 Council Discovery Grant DP0664078 and a Curtin University Targeted Research

296 Fellowship to SMR are gratefully acknowledged. 
298 Ashwal, L.D., Tucker, R.D., Zinner, E.K., 1999. Slow cooling of deep crustal granulites and Pb-loss in zircon. Geochimica et Cosmochimica Acta, 63, 2839-2851.

Barton Jr., J.M., Blignault, E., 1995. A review of the geochronological constraints on the evolution of the Kaapvaal Craton, South Africa. South African Journal of Geology

Dawson, J.B., Harley, S.L., Rudnick, R.L., Ireland, T.R., 1997. Equilibration and reaction in Archaean quartz-sapphirine granulite xenoliths from the Lace kimberlite pipe, South Africa. Journal of Metamorphic Geology 15, 253-266.

Durrheim, R.J., Nicolaysen, L.O., Corner, B., 1991. A deep seismic reflection profile across the Archean - Proterozoic Witwatersrand basin, South Africa. Continental Lithosphere: Deep Seismic Reflections. AGU Geodyn. Ser., vol. 22, pp. 213224.

Flemming, R.L., 2007. Micro X-ray diffraction ( $\mu$ XRD): a versatile technique for characterization of Earth and planetary materials. Canadian Journal of Earth Sciences 44, 1333-1346.

Gibson, R.L., Jones, M.Q.W., 2002. Late Archean to Palaeoproterozoic geotherms in the Kaapvaal craton: constraints on the thermal evolution of the Witwatersrand Basin. Basin Research 14, 169-181.

Gibson, R.L., Reimold, W.U., 2005. Shock pressure distribution in the Vredefort impact structure, South Africa. Geol. Soc. Amer. Spec. Pap. 384, 329-349.

Harley, S.L., Kelly, N.M., Moeller, A., 2007. Zircon behaviour and the thermal histories of mountain chains. Elements 3, 25-30.

Hayward, C.L., Reimold, W.U., 2005. Gold mineralization within the Witwatersrand Basin, South Africa: evidence for a modified placer origin, and the role of the Vredefort impact event. Geol. Soc. London, Special Publications 248, 31-58.

Henkel, H., and Reimold, U.W., 1998. Integrated geophysical modelling of a giant, complex impact structure: anatomy of the Vredefort Structure, South Africa. Tectonophysics 287. 
Henkel, H., and Reimold, U.W., 2002. Magnetic model of the central uplift of the Vredefort impact structure, South Africa. Journal of Applied Geophysics 51, 4362.

Holmes, A., 1911. The association of lead and uranium in rock-minerals, and its application to the measurement of geologic time. Proc. Royal Society (London) 85A, 248-256.

Hoskin, P.W.O., Black, L.P., 2000. Journal of Metamorphic Geology 18, 423-439 (2000). Ivanov, B.A., 2005. Numerical modeling of the largest terrestrial meteorite craters. Solar Syst. Res. 39, 381-409.

Leroux, H., Reimold, W.U., 1999. Experimental shock deformation in zircon: a transmission electron microscopic study. Earth Planet. Sci. Lett. 169, 291-301.

Meldrum, L.A., Boatner, W.J., Weber, J., Ewing, R.C., 1998. Radiation damage in zircon and monazite. Geochimica et Cosmochimica Acta 62, 2509-2520.

Moser, D.E., 1997. Dating the shock wave and thermal imprint of the giant Vredefort impact, South Africa. Geology 25, 7-10.

Moser, D.E. and Heaman, L.M., 1997. Proterozoic zircon growth in Archean lowercrustal xenoliths, southern Superior craton - a consequence of Matachewan ocean opening, Contributions to Mineralogy and Petrology, 128: 164-175.

Moser, D.E., R. Flowers, R., Hart, R.J., 2001. Birth of the Kaapvaal tectosphere 3.08 billion years ago. Science 291, 465-468.

Moser, D.E., Bowman, J.R., Wooden, J., Mazdab, F., Valley, J.W., Kita, N, 2008. Creation of a continent recorded in zircon zoning. Geology, 36, 239-242.

Nguuri, T.K., Gore, J., 2001. Crustal structure beneath southern Africa and its implications for the formation and evolution of the Kaapvaal and Zimbabwe cratons. Geophys. Res. Lett. 28, 2501-2504.

Nimmo, F., Hart, S.D., Korycansky, D.G., Agnor, C.B., 2008. Implications of an impact origin for the martian hemispheric dichotomy, Nature 453, 1220-1223.

Pattison, D.R.M., 2003. Petrogenetic significance of orthopyroxene-free garnet + clinopyroxene+plagioclase + or - quartz-bearing metabasites with respect to the amphibolite and granulite facies. Journal of Metamorphic Geology 21, 21-34. 
356 Phillips, D., Machin, K.J., Kiviets, G.B., Fourie, L.F., Roberts, M.A., Skinner, E.M.W., 1998. A petrographic and ${ }^{40} \mathrm{Ar} /{ }^{39} \mathrm{Ar}$ geochronological study of the Voorspoed kimberlite, South Africa: Implications for the origin of Group II kimberlite magmatism. South African Journal of Geology 101, 299-306.

Pidgeon, R.T., Nemchin, A.A., van Bronswijk, W., Geisler, T., Meyer, C., Compston, W., Williams, I.S., 2007. Complex history of a zircon aggregate from lunar breccia 73235. Geochimica et Cosmochimica Acta 71, 1370-1381.

Reddy, S.M., N.E. Timms, N.E., Buchan, C., Trimby, P., Blake, K., 2006. Crystal-plastic deformation of zircon: A defect in the assumption of chemical robustness. Geology 34, 257-260.

Reddy, S.M., Timms, N.E., Pantleon, W., Trimby, P., 2007. Quantitative characterization of plastic deformation of zircon and geological implications. Contributions to Mineralogy and Petrology 153, 625-645.

Reddy, S.M., Timms, N.E., 2008. Electron backscatter diffraction analysis of zircon: A systematic assessment of match unit characteristics and pattern indexing optimization. American Mineralogist, 93, 187-197.

Rubatto, D., 2002. Zircon trace element geochemistry: partitioning with garnet and the link between U-Pb ages and metamorphism. Chemical Geology 184, p.123-138.

Schmitz, M.D., Bowring, S.A., 2003. Ultrahigh-temperature metamorphism in the lower crust during Neoarchean Ventersdorp rifting and magmatism, Kaapvaal Craton, southern Africa. Geol. Soc. Amer. Bull. 115, 533-548.

Snoke, A.W., Tullis, J., 1998. in Fault-related Rocks-a Photographic Atlas, A.W. Snoke, J. Tullis, Eds. (Todd, Princeton, N.J).

Spray, J.G. , Kelley, S.P. and Reimold, W.U. 1995. Laser-probe ${ }^{40} \mathrm{Ar} /{ }^{39} \mathrm{Ar}$ dating of coesite- and stishovite-bearing pseudotachylytes and the age of the Vredefort impact event. Meteoritics 30, 335-343.

Srinivasan, G., M. J. Whitehouse, M.J., Weber, I., Yamaguchi, A., 2007. The crystallization age of eucrite zircon. Science 317, 345-347.

Stacey, J.S. and Kramers, J.D., 1975. Approximation of terrestrial lead isotope evolution 386 
387 Wayne, D.M., Sinha, A.K., 1988. Physical and chemical response of zircons to 388 deformation. Contrib Mineral Petrol 98, 109-121.

389 Wetherill, G.S., 1956. An interpretation of the Rhodesia and Witwaterstrand age patterns. $390 \quad$ Geochim Cosmochim Acta 9 : 290-292.

391 Wilde, S.A., Valley, J.W., Peck, W.H., Graham, C.M., 2001. Evidence from detrital zircons 392 for the existence of continental crust and oceans on the Earth 4.4 Gyr ago. Nature $393 \quad 409,175-178$.

394

395 Supplementary Material

396 Methods

397 Figs. S1, S2, S3

398 Tables. S1, S2, S3

399 
Figure Legends

402 Figure 1: Basement geology map of the Kaapvaal craton showing the central uplift of the

$4032.020 \mathrm{Ga}$ Vredefort impact basin, and the location of the $0.132 \mathrm{Ga}$ Lace kimberlite pipe

404 from which the mafic granulite xenoliths were collected. Dashed ring represents former

405 trace of the $\sim 250 \mathrm{~km}$-diameter crater on the now deeply eroded craton.

407 Figure 2: SEM backscatter electron (BSE) image of thin section of xenolith LG-6

408 showing; A, zircon included in garnet porphyroclast, and; B and C, zircons at garnet edge

409 within the enveloping mylonitic fabric. Magnified CL images show type 1 (igneous,

410 garnet-absent) cores and type 2 (recrystallized, garnet present) rims; both of which are

411 interpreted to have remained undeformed (see $\mu$ XRD point pattern) since $2.67 \mathrm{Ga}$.

412 Zircons in the mylonitic grain fabric show more complex type 3 zoning and crystal-

413 plastic strain (note arc-shaped lattice plane reflections in $\mu$ XRD patterns).

415 Figure 3: U-Pb Concordia plots showing results of ID-TIMS dating of single zircons from 416 all xenoliths (above) and SHRIMPII dating of xenoliths LG1, LG2 (below). The data 417 demonstrate variable $\mathrm{Pb}$-loss from original $2.67 \mathrm{Ga}$ zircon along a discordia line to 2.02

418 Ga. The high isotopic resolution ID-TIMS demonstrates clearly that data lie beneath 419 concordia and are discordant. The high spatial resolution SHRIMPII dating permits 420 correlation of discordance with specific zircon domains identified by CL, and

421 microstructural analysis. Only by combining the complimentary strengths of these

422 techniques can we demonstrate a strain-induced discordance event that overlaps the time 423 of Vredefort impact basin dynamics at 2020 \pm 3 Ma. 
425 Figure 4: TOP; grayscale SEM-CL image of polished zircon LG-2a Grain 17 showing ion

426 probe pits and corresponding ${ }^{207} \mathrm{~Pb} /{ }^{206} \mathrm{~Pb}$ model ages. Degree of $\mathrm{Pb}$ - loss experience by

427 each ion pit volume was calculated based on position on chord between $2.670 \mathrm{Ga}$ and

428 2.020 Ga. MIDDLE: Orientation contrast image of same grain, following removal of ion

429 probe pits, generated with EBSD and indicating relative concentration of low angle grain

430 boundaries in central corridor. Superposition of $\mathrm{Pb}$-loss contours indicates a spatial

431 correlation between central N-S trending, corridor of subgrain boundaries with a zone of

432 complete U-Pb isotopic resetting of the U-Pb system at $2.02 \mathrm{Ga}$. The youngest ${ }^{207} \mathrm{~Pb} /{ }^{206} \mathrm{~Pb}$

433 ages $(n=6)$ from this microstructure are interpreted to directly date crystal-plastic

434 deformation. MIDDLE inset: A $\mu$ XRD pattern of Grain 17 following ion probe analysis.

435 Note short arcs on zircon (112) and (321) lattice planes indicating bulk crystal plastic

436 strain of the grain with a mosaicity of 3 degrees identical to deformed zircons in

437 mylonitic zones in thin section LG-6 (Note that faint ring patterns are due to clay in paper

438 masking neighbouring zircons on SHRIMP mount). BOTTOM: EBSD measurements of

439 lattice rotation and stereonet projection of poles to lattice planes indicating distortion

440 accommodated by multiple slip systems.

442 Figure 5: Schematic, cross-sectional view of thermal, pressure and motion fields beneath

443 the central zone of the Vredefort impact basin (modified after Henkel and Reimold (1998;

444 2002) at time of impact at $2020 \pm 3 \mathrm{Ma}$ indicating the location of the $132 \mathrm{Ma}$ Lace

445 kimberlite pipe and the source region of the mafic mylonite xenoliths containing the

446 ductile zircon analyzed in our study. The impact-generated mylonitic fabrics formed at 
447 the same distance from impact center as gently upturned seismic reflectors in the crust-

448 mantle transition reported by Durrheim et al. (1991) and may represent post-impact

449 ductile flow across the region during recovery of the multi-kilometer deep crater.

450 
Click here to download Table: Moser et al IDTIMS Table 1.pdf

TABLE S1. ID-TIMS U-Pb data

\begin{tabular}{|c|c|c|c|c|c|c|c|c|c|}
\hline $\begin{array}{l}\text { Fraction number/ } \\
\text { description }{ }^{\mathrm{a}} \text { ) }\end{array}$ & $\begin{array}{r}\text { Weight } \\
{[\mu \mathrm{g}]}\end{array}$ & $\begin{array}{r}\left.U^{b}\right) \\
{[p p m]}\end{array}$ & $\begin{array}{r}\left.\mathrm{Pb}_{\text {com }}{ }^{\mathrm{C}}\right) \\
{[\mathrm{pg}]}\end{array}$ & $\left.\mathrm{Th} / \mathrm{U}^{\mathrm{d}}\right)$ & $\begin{array}{l}{ }^{206} \mathrm{~Pb} / \\
\left.{ }^{204} \mathrm{~Pb}^{\mathrm{e}}\right)\end{array}$ & $\begin{array}{l}{ }^{206} \mathrm{~Pb} / \\
\left.{ }^{238} \mathrm{U}^{f}\right)\end{array}$ & $\begin{array}{l}{ }^{207} \mathrm{~Pb} / \\
\left.{ }^{235} \mathrm{U}^{f}\right)\end{array}$ & $\begin{array}{l}{ }^{207} \mathrm{~Pb} / \\
\left.{ }^{206} \mathrm{~Pb}^{\mathrm{f}}\right)\end{array}$ & $\begin{array}{l}{ }^{207} \mathrm{~Pb} / \\
\left.{ }^{206} \mathrm{~Pb}^{\dagger}\right)[\mathrm{Ma}] \text { (\%disc) }\end{array}$ \\
\hline \multicolumn{10}{|l|}{ Xenolith LG1 } \\
\hline LG1-Z3 & 2 & 470 & 1.3 & 0.49 & 18921 & $0.4193 \pm 14$ & $8.660 \pm 30$ & $0.14978 \pm 18$ & $2343 \pm 2(4.3 \%)$ \\
\hline LG1-4--ZB & 2 & 650 & 1.4 & 0.57 & 26601 & $0.4391 \pm 10$ & $9.498 \pm 22$ & $0.15690 \pm 18$ & $2423 \pm 2(3.8 \%)$ \\
\hline LG1-4--ZC & 4 & 540 & 2.3 & 0.67 & 28670 & $0.4673 \pm 10$ & $11.212 \pm 28$ & $0.17073 \pm 20$ & $2565 \pm 2(2.5 \%)$ \\
\hline \multicolumn{10}{|l|}{ Xenolith LG2 } \\
\hline LG2A-1ZA & 1 & 630 & 1.2 & 0.55 & 30701 & $0.4845 \pm 12$ & $11.574 \pm 30$ & $0.17328 \pm 22$ & $2590 \pm 2(2.0 \%)$ \\
\hline LG2B-1ZA & 2 & 1460 & 1.4 & 0.50 & 65501 & $0.4930 \pm 10$ & $12.005 \pm 28$ & $0.17660 \pm 16$ & $2621 \pm 2(1.7 \%)$ \\
\hline LG2B-1ZC & 2 & 1180 & 1.6 & 0.51 & 47550 & $0.5041 \pm 10$ & $12.462 \pm 30$ & $0.17928 \pm 16$ & $2646 \pm 1(0.7 \%)$ \\
\hline \multicolumn{10}{|l|}{ Xenolith LG3 } \\
\hline \multicolumn{10}{|l|}{ Xenolith LG5 } \\
\hline LG5-Z1 & 2.5 & 210 & 0.6 & 0.49 & 29317 & $0.4907 \pm 12$ & $11.839 \pm 30$ & $0.17498 \pm 18$ & $2606 \pm 2(1.5 \%)$ \\
\hline LG5-Z2 & 4 & 200 & 0.8 & 0.45 & 58193 & $0.4559 \pm 14$ & $10.289 \pm 30$ & $0.16367 \pm 28$ & $2894 \pm 3(3.5 \%)$ \\
\hline \multicolumn{10}{|l|}{ Xenolith LG6 } \\
\hline LG6-Z1 & 1 & 530 & 0.7 & 0.46 & 25940 & $0.5072 \pm 12$ & $12.573 \pm 32$ & $0.17980 \pm 20$ & $2651 \pm 2(0.3 \%)$ \\
\hline LG6-Z2 & 1 & 200 & 1.0 & 0.48 & 6611 & $0.5082 \pm 16$ & $12.632 \pm 42$ & $0.18026 \pm 24$ & $2655 \pm 2(0.3 \%)$ \\
\hline
\end{tabular}

${ }^{\text {a) }}$ Unless otherwise stated all the zircons are clear, transparent grains, from least paramagnetic fractions of Frantz separates, free of cracks and inclusions. In this case all are single grain, or grain-fragment, analyses.

$\left.{ }^{b}\right) \cup$ concentrations known to better than $5 \%$ for sample weights over $50 \mu \mathrm{g}$ and about $50 \%$ for sample weights below $2 \mu \mathrm{g}$.

c) Total common $\mathrm{Pb}$ (corrected for fractionation and spike); assigned to blank and subtracted from total $\mathrm{Pb}$ for age calculations.

d) Model Th/U inferred from ${ }^{208} \mathrm{~Pb} /{ }^{206} \mathrm{~Pb}$ using the ${ }^{207} \mathrm{~Pb} /{ }^{206} \mathrm{~Pb}$ age.

e) corrected for fractionation and spike.

$\left.{ }^{f}\right)$ corrected for fractionation, spike, blank $\mathrm{Pb}$, and initial common $\mathrm{Pb}$ if total common $\mathrm{Pb}>5 \mathrm{pg}$. Initial $\mathrm{Pb}$ composition estimated using Stacey and Kramers (1975) model. Uncertainty estimated with error propagation procedure that accounts for measurement errors, blank uncertainties and reproducibility of $\mathrm{Pb}$ and $\mathrm{U}$ standards and the effect of an uncertainty of $\pm 2 \%$ on the initial $\mathrm{Pb}$ composition and $1 \%$ on the blank $\mathrm{Pb}$ composition. Uncertainties on ratios and ages are quoted at 2 sigma level of confidence. 
Figure 2

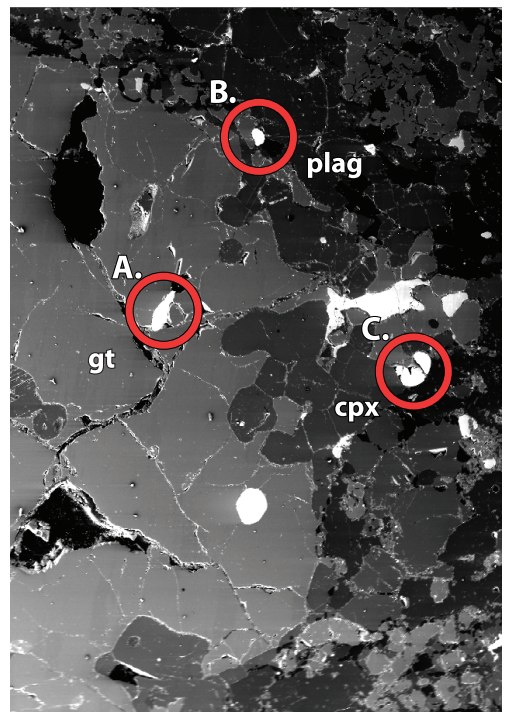

\section{BSE}

In situ SEM-CL and micro-XRD data for zircon at center and margin of garnet porphyroclast in thin section LG-6 indicating zircon strain coeval with mylonitization.

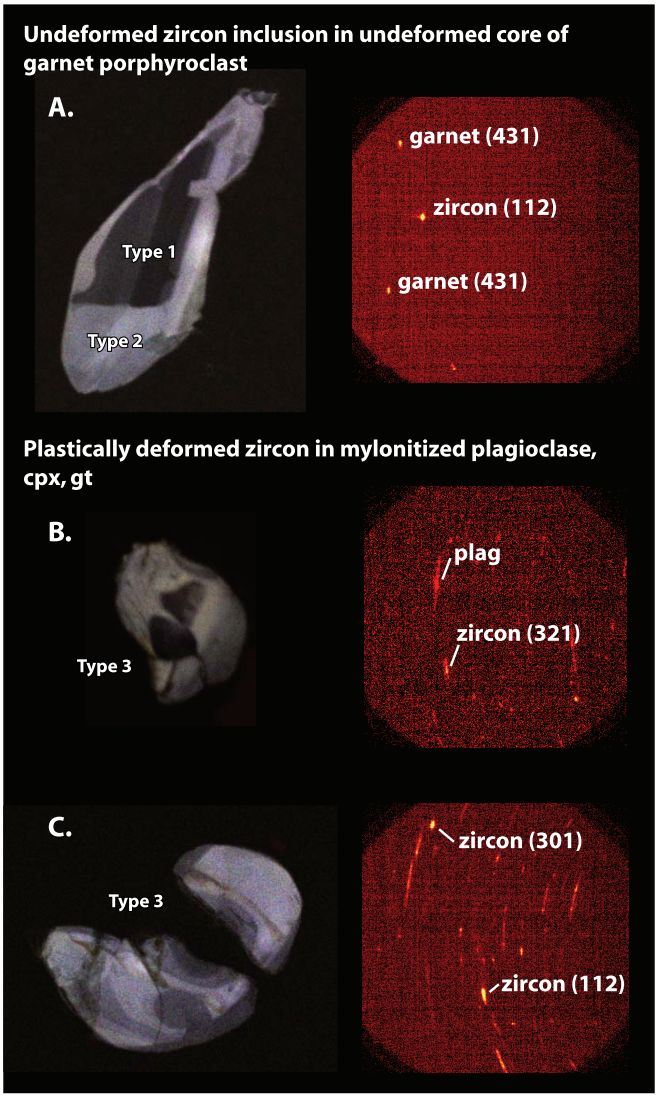

SEM-CL $\mu$ XRD 
Figure 3

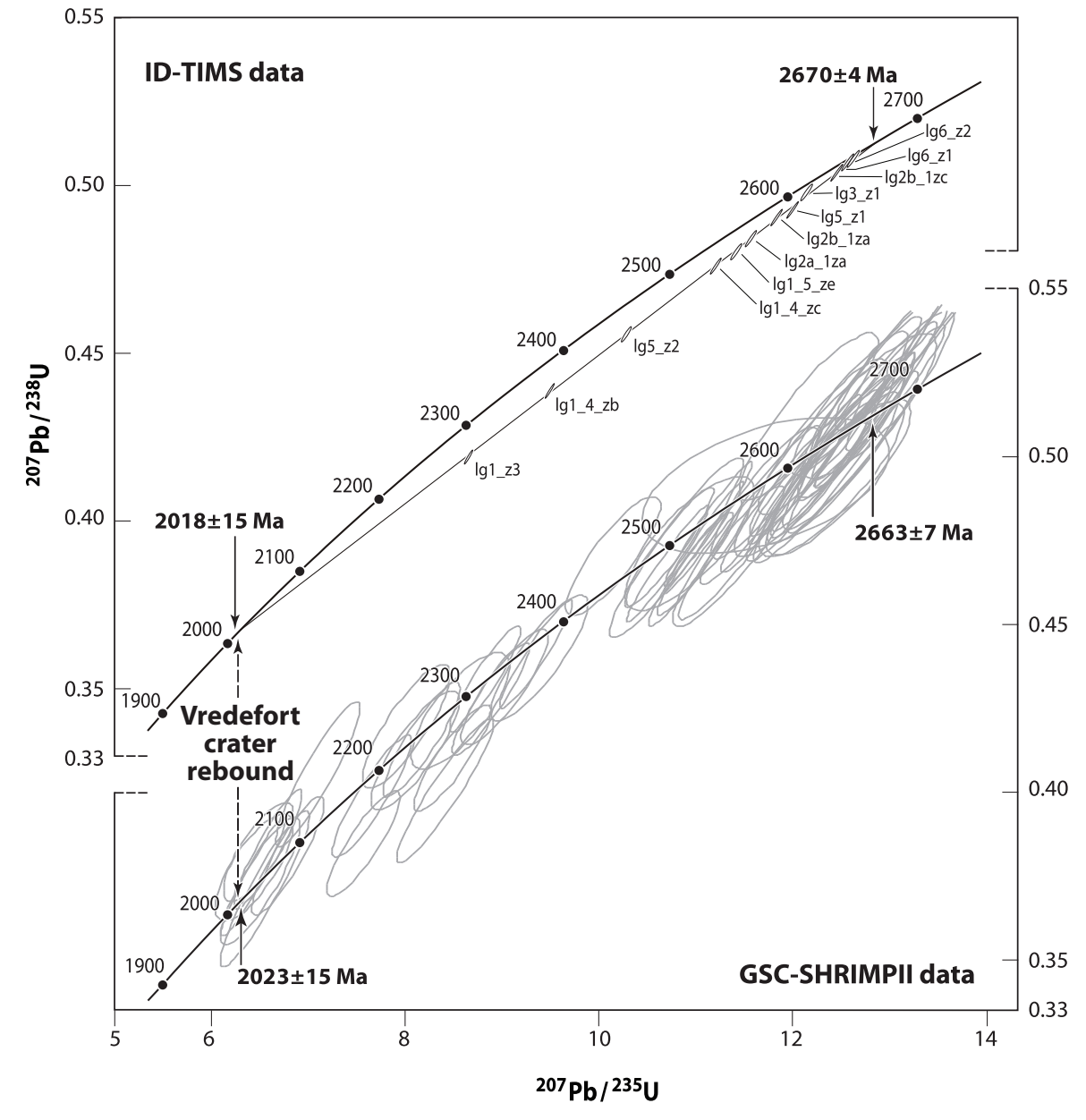




\section{Figure 4}

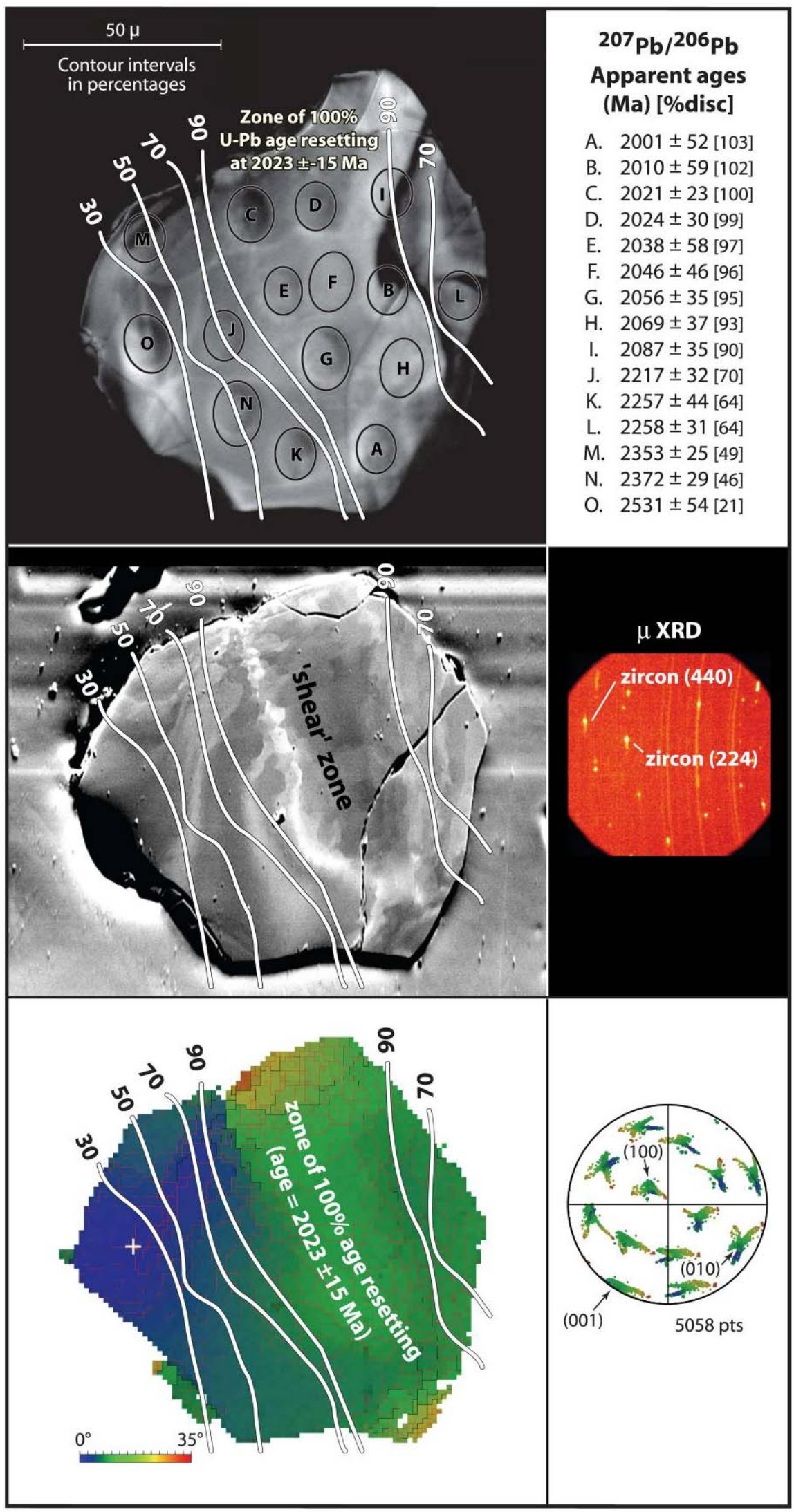




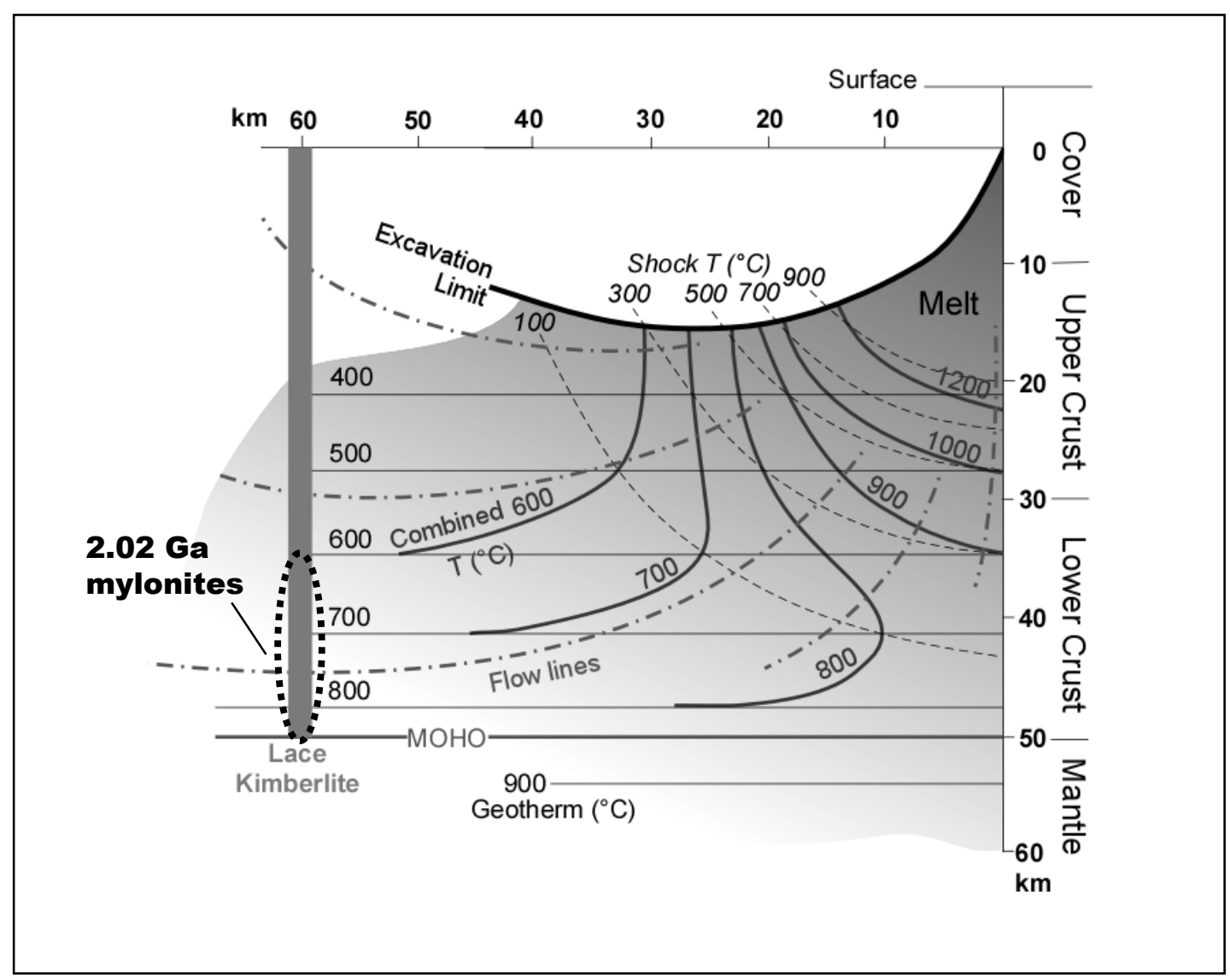

Fig. 5: Moser et al. 